\title{
Legal Perspective on the Supporting Role of Human Resource in the Islamic Banking Industry in Indonesia
}

\author{
Renny Supriyatni
}

Faculty of Law, Universitas Padjadjaran, Indonesia

\begin{abstract}
The purpose of this study is to search for and find a model for developing human resources competencies based on Islamic values in Islamic banking in Indonesia. The study was a descriptive-analytical study with a normative juridical approach by using library research. The findings in this study are the human resources competency development model based on Islamic values in Islamic banking in Indonesia is to use the concept of professional qualifications and employment in the Islamic banking financial industry with the criteria and concepts of having hard \& soft skills competencies, including honest, transparency, trustworthy, and personal development based on worship, faith, science, charity, and missionary endeavor.
\end{abstract}

Keywords: Basic competence, human resources, skills, competencies, Islamic banks.

\section{INTRODUCTION}

Islamic banking is a subsector of the Islamic financial industry. its functions are raising funds, channeling funds, and providing banking services to its customers. In its implementation, the sharia banking industry refers to sharia principles that are regulated and monitored by several institutions and teams. These include the National Sharia Council of the Indonesian Ulema Council (DSN-MUI), the Financial Services Authority (hereinafter OJK), and the Sharia Supervisory Board (DPS) contained within the company. The flow of sharia banking clusters in the Indonesian Sharia Economic Master Plan 2019-2024 will begin with a discussion of the condition and development of sharia banking at the global and national level. Furthermore, the National Sharia Banking Policy Direction in the blueprint Development of National ShariaBanking stated that one of the targets was identified the problem of lack of adequate human resources both in quality and quantity. This is in line with the National Strategic Plan in developing Islamic finance, in point iv increasing the quantity and quality of its human resources (Global Islamic EconomyReport, 2018). Achievement of the Indonesian Islamic banking market share over the past 20 years is still at $5 \%$, despite various efforts made by stakeholders through policies to increase market share by the target.

Islamic banking attracts the attention of many people both academics and economic/banking practitioners because it has differences in overcoming economic problems based on Islamic Sharia teachings.

*Address correspondence to this author at the Jl. Bandung Sumedang KM. 21, Jatinangor, Sumedang, West Java 45363, Indonesia; Tel: 022-84288827; E-mail: rennysupriyatni.unpad@gmail.com
Thus, it can be categorized that Islamic banking is a financial institution based on the Koran and as-Sunnah, as a source of Islamic law. Islamic norms encourage social responsibility in the form of alms and endowments. Thus, besides developing Islamic banking, support is also needed. In terms of human resources, Indonesia can take advantage of global opportunities (Mukhlasin, 2016). This research examines the urgency of accelerating the growth and development of sharia financial institutions, particularly sharia banking in Indonesia, which has indicated the need for the readiness of Human Resources in the Financial Services Industry especially sharia banking. The HR can encourage the acceleration of the growth rate of Islamic finances. Besides, the availability of qualified $H R$ is expected to significantly increase public confidence in Islamic banks. It can even improve product innovation services, and sharia compliance, especially in dealing with Islamic bank disputes. The problem is, how is the Human Resources competency development model based on Islamic values in Islamic banking in Indonesia. This study aims to find a model for developing Human Resources competencies based on Islamic values in Islamic banking in Indonesia.

\section{RESEARCH METHODS}

The research specifications used in this study are descriptive-analytical by exploring the role of human resources in developing the qualified Islamic banking sector in Indonesia. The descriptive approach aims to provide a complete and systematic picture of the facts about the role of human resources and the development of sharia banking. The analytical approach was conducted by analyzing the statutory provisions that apply in Islamic banking activities and operations. This study uses a normative juridical 
approach (Soemitro, 1988) namely legal research conducted by examining, and testing library materials or so-called secondary data aimed at reviewing and analyzing Islamic banking activities and operations. The stages of the study began with library research, aimed at obtaining secondary data (Hartono, 2014). Primary legal materials and secondary legal materials, in the form of books, legal journals, economics, sharia/Islamic finance, and banking papers, and previous research results. Furthermore, the data obtained from the results of the study will be analyzed in a qualitative juridical manner, which is a research method that starts from legal regulations/provisions, both in the form of laws and other regulations by positive legal norms and Islamic law. as well as a review of several provisions/regulations and agreement documents.

\section{RESULTS}

The implementation starts with the 2017-2019 Road Map for the development of Islamic finance with a vision to create a sharia financial services industry that grows and is sustainable, equitable and contributes to the national economy and financial system stability towards the realization of Indonesia as the center of sharia financial world. This vision is outlined in the mission outlined in three strategic objectives including increasing institutional capacity and availability of sharia financial industry products that are more competitive and efficient, expanding access to Islamic financial products and services to meet the needs of the community; and increasing the inclusion of Islamic financial products and coordinating with stakeholders to enlarge the market share of Islamic finance (Idat et al., 2018). The strategic objectives of increasing the inclusion of Islamic financial products and coordinating with stakeholders to enlarge the market share of Islamic finance is through increasing the capacity of human resources by empowering industry associations in improving the quality of human resources of Islamic finance.

Also, Indonesia has the potential and strength to become a major player in international Islamic finance (Idat et al., 2018). Even the growth and development of the Islamic economic and financial sector in Indonesia shows graphs increasing from time to time. At the international level, Indonesia is seen as a strength and has great potential in global Islamic finance - the 10 largest countries in the field of Islamic finance along with the United Arab Emirates (UAE), Saudi Arabia, Malaysia, and Bahrain. Indonesia is now considered to be in a position to offer lessons to other countries in the world for the development of Islamic finance. Also, along with Qatar, Saudi Arabia, Malaysia, UAE, Turkey (QISMUT), Indonesia is considered as the driving force of Islamic finance in the future. Therefore, one of the challenges facing Indonesia is the inadequate quantity and quality of human resources in supporting the development of sharia-based products and services.

The real effort is needed on an ongoing basis to be able to achieve the quantity and quality of human/human resources needed, to be able to encourage the Islamic financial services sector in producing products and services that are by the public expectations. Also, public understanding and awareness of sharia services and products are still relatively low. These two strategic issues are interrelated with one another, with the increasing quantity and quality of human resources, it is hoped that the Islamic financial industry will be able to provide the understanding and increase the level of public knowledge and awareness of sharia-based services and products. Indonesia is currently ranked in the top 10 in the world (Mukhlasin, 2016).

Table 1: Top 10 Islamic Finance Asset

\begin{tabular}{|c|c|c|}
\hline No & Country & Asset (\$ Million) \\
\hline \hline 1 & Malaysia & 423,285 \\
\hline 2 & Saudi Arabia & 338,106 \\
\hline 3 & Iran & 323,300 \\
\hline 4 & UAE & 140,289 \\
\hline 5 & Kuwait & 92,403 \\
\hline 6 & Qatar & 81,027 \\
\hline 7 & Bahrain & 64,644 \\
\hline 8 & Turkey & 51,161 \\
\hline 9 & Indonesia & 19,938 \\
\hline 10 & Bangladesh & 14,647 \\
\hline
\end{tabular}

Source: Word Islamic Banking Comparativeness Report 2014-2015, EY and MEGA.

Some important things can be raised regarding problems in Islamic banking in Indonesia. First, large market potential is not accompanied by a large market share growth, given the majority of Indonesia's Muslim population. Second, the condition of Islamic banking human resources, both in terms of quantity and quality, as well as information technology that has not been able to support the development of products and services. Third, based on Indonesian banking statistics from December 2014 to May 2017, when compared to 
the performance of Islamic banking with conventional banking, in various measures of performance assessment of the banking industry, namely CAR, ROA, BOPO, LDR/FDR, NIM/NOM, NPL/NPF are under conventional performance.

Fourth, efforts to improve regulation have not been maximized so that it must continue to be carried out to create harmony in sharia banking operations with changing conditions in the macroeconomy. Fifth, research and development aspects that still need to be developed to find out the latest conditions, both regarding opportunities, challenges, as well as advantages and disadvantages they have. Finally, education and socialization that are not yet inclusive and touch the wider community must be carried out so that the growth and sustainability of the Islamic financial and banking industry can be as targeted.

Furthermore, the application of the dual banking system in Indonesia, in forms of conventional and sharia banking side by side with a separate administrative system (Bachro et al., 2013). Law Number 21 of 2018 specifically regulates sharia principles that must be obeyed by Islamic banks and types of contracts that can be used by Islamic Banks. This has an impact on the readiness of human resources. HR who understands sharia principles is an important capital to ensure that sharia banking activities comply with sharia compliance and principles.

In the Indonesian context, the readiness and availability of HR who understand Islamic banking is one of the obstacles faced by both the Islamic Bank Financial Industry and by the Financial Services Authority. Even recognized the lack of availability of HR who is competent to oversee the activities of Islamic Bank financial institutions, thus causing oversight is not optimal. Also, the quantity and quality of HR is inadequate and the information system technology is not yet able to support the development of products and services. The preparation of competent HR in the field of sharia banking is comprehensive and adequate and has high integrity, so the synergy is needed between the government, higher education, and sharia financial practitioners and professional organizations in sharia banking (Dussan et al., 2016).

\section{DISCUSSION}

The function of Islam is to increase the degree of prosperity to reduce/negate the five things that have made chronic diseases in the fabric of society with some solutions (Zadjuli, 2009). Community development priorities are arranged to start from the poor and middle class to improve their welfare, then to build up the upper class/able society so that the added value can be partially distributed to disadvantaged/disadvantaged people either through ZIS or unpaid taxes/fees burdensome. Educating and further strengthening human resources both spiritually and physically so that the Human Resources of soul and body are built/formed. It needs to seek a strong future generation both physically and spiritually, uphold justice in all lines based on Islamic sharia in terms of counting, measuring, or weighing in all tijaroh activities, focus on prosperity by implementing resource management: natural, economic, and human resources. For environmentally friendly spatial planning, management of water resources, land, and forest stands is important. In the case of utilizing natural resources, it is necessary to be careful and maintain environmental safety/sustainability in the future.

One form of extracting the potential and form of community contribution in the national economy is the development of an economic system based on Islamic values by elevating its principles into the national legal system. Sharia principles are based on the values of justice, expediency, balance, and universality. These values are applied in banking arrangements based on sharia principles. Sharia banking as one of the national banking systems requires a variety of supporting facilities to be able to make maximum contributions to the development of the national economy. One of the vital supporting facilities is the existence of human resources as the main pillar of the development of Islamic banking.

Setyowati et al. (2018) stated that human resources are the main pillar of the development of Islamic banking. The success of the development of Islamic banking is not only determined by the spectacular growth, preparation, or refinement of the legal provisions, or the number of opening office networks but also is largely determined by the quality of human resources/human beings/practitioners of Islamic banking itself so that Islamic banks can run according to sharia principles and can be utilized by the wider community as part of a financial system that is rahmatan lil alamin. Islamic Bank Human Resources, especially at the middle and upper levels are employees who migrate from conventional banks. It is estimated that 70 percent of sharia bank employees currently come from conventional banks and/or nonsharia educational backgrounds (Dussan et al., 2016). 
Table 2: Composition of Sharia Bank Employees

\begin{tabular}{|c|c|c|c|}
\hline Educational Level & Mandiri Syariah & BNI Syariah & Muamalat \\
\hline \hline Middle School & 262 & 18 & 67 \\
\hline Higher school & 5,226 & 937 & 602 \\
\hline Diploma & 1,502 & 3,119 & 5,838 \\
\hline Undergraduate & 9,856 & 180 & 162 \\
\hline Master & 262 & 1 & - \\
\hline Doctor & - & 4,255 & 6,669 \\
\hline Total & 16,895 & & \\
\hline
\end{tabular}

OJK (2013) targets and objectives the readiness of sharia business and HR to accelerate the growth of the sharia banking finance industry in terms of encouraging financial service sector activities to be carried out regularly, fairly, transparently \& accountably, realizing a financial system that grows sustainably \& stably, and protecting the interests of consumers $\&$ society.

Therefore, in achieving its objectives, OJK supports the interests of the national financial services sector so that it can increase national competitiveness. Besides that, the OJK is expected to be able to safeguard national interests, including, among others, human resources, management, control, and ownership in the financial services sector, while still considering the positive aspects of globalization.

Furthermore, the success of the development of Islamic banking is not only determined by the spectacular growth, preparation, or refinement of the legal provisions, or the number of opening office networks, but also highly determined by the quality of human resources of the actors/practitioners of Islamic banking itself, so that Islamic banks can run according to Islamic principles and can be utilized by the wider community as part of a financial system. According to Dussan et al. (2016), human resources is the main pillar of the development of Islamic banking, while the human resources criteria with the concept of business and sharia compliance.

One of the causes of the low proportion of profitsharing financing is that the competency of Islamic banking is still low to invest in profit-sharing patterns. Abdul-Majid et al. (2011) explained the influence of the quality of Islamic banks on efficiency and productivity in Malaysia. Several studies have also specifically highlighted the competence of Islamic banks in the development and broad consumer interest in using their products (Ashfaque et al., 2020). Khalid et al.
(2018) noted that the competence of Islamic banks has a positive impact on the effectiveness of bank internal audits. Waemustafa (2013) stated that that there is still a generally negative perception regarding the competence and superiority of Islamic banking products compared to commercial banks. Furthermore, Aziz \& Wahid (2019) explained the need to improve the quality of talent and human resource management to prepare Islamic banks that can compete with commercial banks, especially in adopting financial technology in banking (Anggraeni, 2020). Djalil (2015) explains that the performance of Islamic banking and Islamic microfinance is influenced by competitive strategies as the core competencies of Islamic banks. Several kinds of literature that analyze the resource competency of Islamic banks also reveal the findings of the need to increase talent and HR management, such as in Pakistan (Mufti et al., 2016; Bowra et al., 2012), Jordan (Obeidat, 2016), Malaysia (Amin et al., 2014; Abdul-Majid et al., 2011), and Kuwait (Al-Adwani, 2014). Specifically in Indonesia, investment risk is relatively high due to the difficulty of monitoring investment activities, and the principal-agent problem, where the agent does not always act in the interests of the principal (the owner of capital). Here, Islamic banking human resource competencies are still low to invest in profit-sharing patterns and there is also unavailable in-depth business performance information for each industry sector targeted by investment.

Some alternatives that can be done to increase the portion of the profit-sharing financing scheme include: Increasing the competence of HR to invest in profit sharing patterns. Apart from that, that is by Identification of sources of funds. It also can be done by reducing factors that cause agency problems in transactions such as contract standardization, analysis of industry performance indexing. According to Suadi (2017), the strengthening of sharia financial institutions required qualified human resources, especially Islamic 
banking players by strengthening technical implementation and the settlement of Islamic banking disputes. Considering the dominance of non-share financing or the low financing profit-sharing system should be seen proportionally by all stakeholders, including regulators in issuing policies, by taking into account all related aspects, such as aspects of conformity with sharia principles, stages of sharia bank growth, the purity of its operations, and the development of human resources The improvement in the quality and quantity of human resources can be done in stages, starting with the highest level of positions, especially related to the fit and proper test of the managing director of sharia banking regularly and must be distinguished from the fit and proper test for conventional bank leaders. There are also short-term and long-term strategies to improve the quality and quantity of human resources (Bachro et al., 2013).

\section{CONCLUSION}

The human resources competency development model based on Islamic values in Islamic banking in Indonesia is to use the concept of professional qualifications and employment in the Islamic banking financial industry with the criteria and concepts of having hard \& soft skills competencies, including true, honest, transparency, trusted, and personal development. Besides that, it is based on worship, faith, knowledge, practice.

As a recommendation, in the short term, from the internal side of banking, it is necessary to increase training for employees at all levels of position, including the highest level of the position. Meanwhile, in the long run, special education on Islamic economics/banking needs to be promoted, both in the form of separate institutions specifically, and majors in general education.

Practically, the contribution of the findings encourage the mechanism and readiness of human resources in the opportunities and challenges of Islamic banking, are met properly, it is recommended to improve the quality and quantity of human resources can be done in stages, starting with the highest levels of office, through both formal education programs, and non-formal. Specifically related to the fit and proper test of the managing director of sharia banking which is regularly and must be distinguished from the fit and proper test for conventional bank leaders. It should also be noted, what works must be done through an analysis of the company's anatomy and the strategies carried out by the company. Strategy to improve the quality and quantity of human resources, which is expected to change the way of mindset and shape the quality of human resources.

\section{REFERENCES}

Abdul-Majid, M., Saal, D. S., \& Battisti, G. (2011). The impact of Islamic banking on the cost efficiency and productivity change of Malaysian commercial banks. Applied Economics, 43(16), 2033-2054. https://doi.org/10.1080/00036840902984381

Al-Adwani, A. B. (2014). Effects of implementing strategic human resource management on organizational success: Case study of (Kuwait Finance House-KFH). International Business Research, 7(3), 149. https://doi.org/10.5539/ibr.v7n3p149

Amin, M., Ismail, W. K. W., Rasid, S. Z. A., \& Selemani, R. D. A (2014). The impact of human resource management practices on performance. The TQM Journal, 26 (2), 125142. https://doi.org/10.1108/TQM-10-2011-0062

Anggraeni, A. (2020). Executive Role in the Use of Information Technology in Public Organisations. Arthatama, 4(1), 17-32.

Ashfaque, M., Shah, S. M. A., Sultan, F., Khalil, H., Hussain, A., \& Khan, M. (2020). Ethical value propositions of Islamic banking products: A phenomenological inquiry of relationship managers perspective. International Review of Management and Marketing, 10(2), 8-14. https://doi.org/10.32479/irmm.9217

Aziz, M. R. A., \& Wahid, M. A. (2019, October). Talent and Manpower Competency and Readiness in Fintech for Islamic Banking and Finance Program. In e-Proceedings (p. 569).

Bachro, R. S., \& Rukmini, M. (2018). Human Trafficking In Accordance with Prosperity and National Economic Development. Jurnal Cita Hukum, 6(1), 1-18. https://doi.org/10.15408/jch.v6i1.8265

Bowra, Z. A., Sharif, B., Saeed, A., \& Niazi, M. K. (2012). Impact of human resource practices on employee perceived performance in banking sector of Pakistan. African Journal of Business Management, 6(1), 323-332. https://doi.org/10.5897/AJBM11.2312

Djalil, M. A. (2015). The effect of core competency on competitive strategy and its implication on the performance of Islamic banking and Islamic microfinance in the province of aceh, Indonesia. Research Journal of Finance and Accounting, 6(9), 251-264.

Dussan, K., Girisuta, B., Lopes, M., Leahy, J. J., \& Hayes, M. H. (2016). Effects of Soluble Lignin on the Formic Acid-Catalyzed Formation of Furfural: A Case Study for the Upgrading of Hemicellulose. Chem Sus Chem, 9(5), 492504.

https://doi.org/10.1002/cssc.201501415

Hartono, J. (2014). Metode penelitian bisnis. Yogyakarta. Universitas Gadjah Mada.

Idat, M., Gina, A. S., \& Ardi, M. N. (2018, January). How to Improve Service Quality in School Counselling Services?. In IOP Conference Series: Materials Science and Engineering (Vol. 288, No. 1, p. 012083). IOP Publishing. https://doi.org/10.1088/1757-899X/288/1/012083

Khalid, A. A., Haron, H., \& Masron, T. A. (2018). Competency and effectiveness of internal Shariah audit in Islamic financial institutions. Journal of Islamic Accounting and Business Research, 9 (2), 201-221. https://doi.org/10.1108/JIABR-01-2016-0009

Mufti, O., Parvaiz, G. S., Wahab, M., \& Durrani, M. (2016). Human Resource Competencies and Organizational Performance: A 
Study on Banking Sector Managers in Pakistan. Journal of Managerial Sciences, 10(1).

Mukhlasin, H. (2016). Membangun Aplikasi Profesional Berbasis Web Menggunakan Yii Framework. Jakarta: self publishing.

Obeidat, Z. M. (2016). Human Capital Investment And Training In Islamic Banking Industry In Jordan Jordan Islamic Bank for Finance and Investment. European Scientific Journal, 12(10). https://doi.org/10.19044/esj.2016.v12n10p90

OJK. (2013). Perkembangan Hukum Ekonomi dan Dampaknya terhadap Pembentukan Perundangan-undangan dan Penegakan Hukum. Presented at Master of Law Studies Program, Faculty of Law, UNPAD, Bandung, November 14, 2013

Setyowati, R. F., Purbasari, I., \& Fauzan, E. M. (2018). Consumers Spiritual Rights in the Islamic Banking Dispute Out of Court Settlement. Journal of Social Studies Education Research, 9(4), 334-351.
Soemitro, R. H. (1988). Teori dan Metodologi Penelitian Hukum Normatif.

Suadi, A. (2018). Peluang dan Tantangan Lembaga Keuangan Syariah Dalam Menghadapi Era Pasar Bebas/Opportunities And Challenges Of Sharia Financial Institutions In Dealing With Free Market. Jurnal Hukum dan Peradilan, 7(1), 1-22. https://doi.org/10.25216/JHP.7.1.2018.1-22

Waemustafa, W. (2013). The emergence of Islamic banking: Development, trends, and challenges. IOSR Journal of Business and Management (IOSR-JBM), 7(2), 67-71. https://doi.org/10.9790/487X-0726771

Zadjuli, S. I. (2009). Sistim Penidikan dan Ekonomi Islam Sebagai Solusi Meniadakan Kemiskinan dan Ketidak Adilan dalam Rangka Membangun Masyarakat Madhani Secara Kafah. Makalah pada semiloka Ekonomi Islam Sebagai Sistem Pendidikan IImu Ekonomi di Indonesia di Auditorium Mo. Djazman UMS-Surakarta.

Received on 15-12-2020

DOI: https://doi.org/10.6000/1929-4409.2021.10.36

(C) 2021 Renny Supriyatni; Licensee Lifescience Global.

This is an open access article licensed under the terms of the Creative Commons Attribution Non-Commercial License (http://creativecommons.org/licenses/by-nc/3.0/) which permits unrestricted, non-commercial use, distribution and reproduction in any medium, provided the work is properly cited. 